\title{
The value of control conditions for evaluating pharmacogenetic effects
}

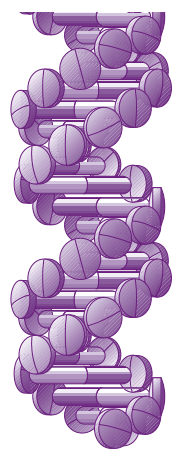

The article by Leung et al. [1] provides a metaanalysis of CHRNA5-CHRNA3-CHRNB4 rs16969968-rs1051730 and smoking cessation in the context of six treatment trials where all participants received nicotine replacement therapy. The authors found no evidence of significant association between the variant and successful smoking cessation, and in keeping with this, the authors conclude that "the alleles of rs1051730 and rs16969968 are not associated with smoking cessation." It is possible that this statement is essentially, universally true. However, we would like to emphasize that the authors' conclusion is based on analyses of trial data that comprised no placebo controls. It is possible that the genetic variants in question exert different effects in the presence of active pharmacotherapy versus placebo. For example, multiple genes can predict coronary artery disease outcomes, but examination of only individuals treated with statins will not reveal some of the genetic associations because these medications modify the genetic effect [2]. Similarly, the CHRNA5 effect on smoking cessation may be moderated by nicotine replacement therapy [3], suggesting that meta-analyses of pharmacogenetic effects should include both placebo and active treatment arms. Indeed, many authors have urged that pharmacogenetic research such as the Leung et al. study analyze both placebo and active medication arms to fully understand genetic modifiers of treatment [4-6].

It is likely that some of the variability in genetic relations across studies and analyses reflects the complex moderation of genetic effects by environmental factors such as treatment, comorbidities and environmental events such as stressors and social contexts [3,7-8]. The genetic effect of CHRNA5 on smoking cessation has been demonstrated in some research studies [3,7,9-15], but not in several other important studies [16-19]. We believe that such variability reflects the actions of important moderators related to treatment and sample characteristics. While the Leung et al. [1] study was not intended to detect such moderation, we believe that further research on such effects is needed for a methodologically principled approach to the application of Precision Medicine in order to best help out patients quit smoking.

Financial \& competing interests disclosure L-S Chen receives support from NIH (K08 DA030398, R01 DA038076). LJ Bierut receives support from NIH (R01 DA036583, R01 DA025888, K02 DA021237). TB Baker receives support from NIH (P50 CA84724, K05 CA139871, P50 DA19706). LJ Bierut is listed as an inventor on issued US Patent 8,080,371, 'Markers for Addiction' covering the use of certain SNPs in determining the diagnosis, prognosis, and treatment of addiction. The authors have no other relevant affiliations or financial involvement with any organization or entity with a financial interest in or financial conflict with the subject matter or materials discussed in the manuscript apart from those disclosed.

No writing assistance was utilized in the production of thismanuscript.
Li-Shiun Chen*,1, Timothy B Baker $^{2}$ \& Laura J Bierut ${ }^{1}$

'Department of Psychiatry, Washington University School of Medicine, St. Louis, MO, USA

${ }^{2}$ Tobacco Research and Intervention, University of Wisconsin, School of Medicine, Madison, WI, USA *Author for correspondence: smockn@psychiatry.wustl.edu 


\section{References}

1 Leung T, Bergen A, Munafo MR, De Ruyck K, Selby P, De Luca V. Effect of the rs1051730-rs16969968 variant and smoking cessation treatment: a meta-analysis. Pharmacogenomics 16(7), 713-720 (2015).

2 Mega JL, Stitziel NO, Smith JG et al. Genetic risk, coronary heart disease events, and the clinical benefit of statin therapy: an analysis of primary and secondary prevention trials. Lancet 385(9984), 2264-2271 (2015).

3 Chen LS, Baker TB, Piper ME et al. Interplay of genetic risk factors (CHRNA5-CHRNA3-CHRNB4) and cessation treatments in smoking cessation success. Am. J. Psychiatry 169(7), 735-742 (2012).

4 Heitjan DF, Guo M, Ray R, Wileyto EP, Epstein LH, Lerman C. Identification of pharmacogenetic markers in smoking cessation therapy. Am. J. Med. Genet. B Neuropsychiatr. Genet. 147B(6), 712-719 (2008).

5 Singer C, Grossman I, Avidan N, Beckmann JS, Pe'er I. Trick or treat: the effect of placebo on the power of pharmacogenetic association studies. Hum. Genomics 2(1), 28-38 (2005).

6 Wang SJ, O'neill RT, Hung HJ. Statistical considerations in evaluating pharmacogenomics-based clinical effect for confirmatory trials. Clin. Trials 7(5), 525-536 (2010).

7 Chen LS, Hung RJ, Baker T et al. CHRNA5 risk variant predicts delayed smoking cessation and earlierlung cancer diagnosis - a meta-analysis. J. Natl Cancer Inst. 107(5), pii: djv100 (2015).

8 Chen LS, Baker TB, Piper ME et al. Interplay of genetic risk (CHRNA5) and environmental risk (partner smoking) on cigarette smoking reduction. Drug Alcohol Depend.143, 36-43 (2014).

9 Baker TB, Weiss RB, Bolt D et al. Human neuronal acetylcholine receptor A5-A3-B4 haplotypes are associated with multiple nicotine dependence phenotypes. Nicotine Tob. Res. 11(7), 785-796 (2009).

10 Bergen AW, Javitz HS, Krasnow R et al. Nicotinic acetylcholine receptor variation and response to smoking cessation therapies. Pharmacogenet. Genomics 23(2), 94-103 (2013).
11 Freathy RM, Ring SM, Shields B et al. A common genetic variant in the $15 \mathrm{q} 24$ nicotinic acetylcholine receptor gene cluster (CHRNA5-CHRNA3-CHRNB4) is associated with a reduced ability of women to quit smoking in pregnancy. Hum. Mol. Genet. 18(15), 2922-2927 (2009).

12 Munafo MR, Johnstone EC, Walther D, Uhl GR, Murphy MF, Aveyard P. CHRNA3 rs1051730 genotype and shortterm smoking cessation. Nicotine Tob. Res 13(10), 982-988 (2011).

13 Sarginson JE, Killen JD, Lazzeroni LC et al. Markers in the 15 q24 nicotinic receptor subunit gene cluster (CHRNA5$A 3-B 4)$ predict severity of nicotine addiction and response to smoking cessation therapy. Am. J. Med. Genet. B Neuropsychiatr. Genet. 156B(3), 275-284 (2011).

14 Zhu AZ, Zhou Q, Cox LS et al. Association of CHRNA5A3-B4 SNP rs2036527 with smoking cessation therapy response in African-American smokers. Clin. Pharmacol. Ther. 96(2), 256-265 (2014).

15 Sarginson JE, Killen JD, Lazzeroni LC et al. Response to transdermal selegiline smoking cessation therapy and markers in the 15q24 chromosomal region. Nicotine Tob. Res. 17(9), 1126-1133 (2015).

16 Bousman CA, Rivard C, Haese JD, Ambrosone C, Hyland A. Alpha-5 and -3 nicotinic receptor gene variants predict nicotine dependence but not cessation: findings from the COMMIT cohort. Am. J. Med. Genet. B Neuropsychiatr. Genet. 159B(2), 227-235 (2012).

17 Breitling LP, Twardella D, Hoffmann MM, Witt SH, Treutlein J, Brenner H. Prospective association of dopaminerelated polymorphisms with smoking cessation in general care. Pharmacogenomics 11(4), 527-536 (2010).

18 De Ruyck K, Nackaerts K, Beels L et al. Genetic variation in three candidate genes and nicotine dependence, withdrawal and smoking cessation in hospitalized patients. Pharmacogenomics 11(8), 1053-1063 (2010).

19 Tyndale RF, Zhu AZ, George TP et al. Lack of associations of CHRNA5-A3-B4 genetic variants with smoking cessation treatment outcomes in caucasian smokers despite associations with baseline smoking. PLoS ONE 10(5), e0128109 (2015). 